\title{
Telaah Unsur Syariah Aplikasi iB Hasanah Card
}

\author{
Nur Wulandari M1; Syaharuddin²; Sitti Aisyah \\ UIN Alauddin Makassar \\ Jln,. HM Yasin Limpo No.36, Samata-Gowa \\ E-mail : wulandari115@gmail.com¹; syaharuddin_09@gmail.com; s_aisyah@gmail.com
}

Diterima: 4 Juni 2018; Direvisi: 26 Juni 2018; Diterbitkan: 5 Juli 2018

\begin{abstract}
Abstrak,
Penelitian ini bertujuan untuk melihat unsur-unsur syar'i pada aplikasi iB Hasanah Card yang diterbitkan oleh BNI Syariah KCP Pettarani. Untuk itu, maka penelitian ini menggunakan pendekatan kualitatif dengan metode interpretif. Informan yang diambil sebanyak 4 orang yang berasal dari unsur praktisi, akademisi, regulator, dan pengguna kartu (nasabah). Selanjutnya, metode pengumpulan data yang digunakan adalah observasi, dokumentasi, dan wawancara. Kemudian teknik pengolahan dan analisis data yang digunakan adalah reduksi, penyajian, dan penarikan kesimpulan.

Hasil temuan menunjukkan bahwa sebagai Bank Syariah, BNI Syariah berusaha untuk selalu menerapkan prinsip-prinsip syariah dalam menjalankan Hasanah Card. Dilihat dari usaha BNI Syariah dalam menyempurnakan dan terus mengkaji produk kartu kredit syariahnya, dalam usaha menghindari praktek riba, gharar dan israf. Berbagai pihak yang terlibat dalam menyikapi adanya kartu kredit syariah saat ini khususnya di Makassar selain dari praktisi, yaitu akademisi dan regulator yang turut memberi pandangannya. Pihak tersebut menganggap Syariah Card adalah alat yang memudahkan bertransaksi, sebagai alat bantu mengelola manajemen kas keuangan, serta sangat efisien dan aman jika dibanding dengan menggunakan uang tunai.
\end{abstract}

Kata Kunci: Hasanah Card, Ekonomi Islam, Syariah

\section{Abstract,}

This study aims to see the elements of syar'i in the application of iB Hasanah Card issued by BNI Syariah KCP Pettarani. Therefore, this research uses qualitative approach with interpretive method. Informants drawn as many as 4 people from practitioners, academics, regulators, and card users (customers). Furthermore, data collection methods used are observation, documentation, and interviews. Then the processing techniques and data analysis used are reduction, presentation, and conclusion.

The findings show that as a Sharia Bank, BNI Syariah strives to always apply the principles of sharia in the implementation of Hasanah Card. Viewed from the business of BNI Syariah in refining and continuing to review its sharia credit card products, in an effort to avoid the practice of usury, gharar and israf. Various parties involved in addressing the existence of the current credit card sharia especially in Makassar apart from practitioners, namely academics and regulators who also gave his views. The party considers Syariah Card is a tool that facilitates transactions, as a tool to manage cash cash management, and very efficient and safe when compared with using cash.

Keywords: Hasanah Card, Islamic Economics, Sharia 


\section{PENDAHULUAN}

Kebutuhan masyarakat modern saat ini semakin kompleks sehingga menuntut lembaga keuangan syariah untuk senantiasa aktif dan kreatif dalam rangka memberikan respon terhadap perkembangan tersebut. Oleh karena banyaknya permintaan akan pelayanan jasa keuangan maka peran lembaga yang ada dalam hal ini perbankan semakin meningkat. Salah satu produk layanan paling diminati adalah kartu kredit. Kartu kredit atau credit card merupakan gaya hidup dan bagian dari komunitas manusia untuk dapat dikatagorikan modern.

Fenomena pesatnya perkembangan kartu kredit dengan berbagai fasilitas kemudahan yang ada di dalamnya, telah pula mendorong bank syariah atau lembaga keuangan Islam lainnya mencoba untuk ikut menerbitkan kartu kredit islami (islamic credit card). Maka dari itu, berdasarkan fatwa DSN-MUI serta surat persetujuan Bank Indonesia, Bank Nasional Indonesia (BNI) meluncurkan salah satu jenis pembiayaan yang berbasis Kartu Kredit yaitu iB Hasanah Card.

Sejak awal diterbitkannya, Syariah Card memang menimbulkan banyak keraguan dan kontroversi para pelaku perbankan syariah. Para bankir masih meragukan apakah Syariah Card sesuai dengan prinsip-prinsip syariah yang ada dalam transaksi syariah. Lebih dari itu, sebagian pelaku bisnis bank syariah menilai bahwa dari segi manfaat Syariah Card sangat kecil sekali.

Beberapa pendapat tentang Syariah Card ini antara oleh Daud Bakar (2018) dan Muzammil Shiddiqi (2016). Daud Bakar mengutarakan bahwa kartu kredit tidak dikenal dalam Islam, karenanya istilah yang paling tepat digunakan adalah kartu debit. Dengan kata lain, ia pada prinsipnya meragukan tingkat kesyariahan dari Syariah Card tersebut. Adapun Muzammil Shiddiqi berpendapat bahwa penggunaan kartu kredit sama seperti menggunakan sistem perbankan modern yang notabene berbasis riba.

Meskipun banyak pakar yang berpendapat tentang kartu kredit, Dewan Syariah Nasional tetap mengeluarkan fatwa tentang hukum kebolehan kartu kredit, yaitu fatwa No. 54/DSN-MUI/X/2006 tentang Syariah Card. ${ }^{1}$ Didalam fatwa DSN-MUI No. 54 tentang Syariah Card terdapat beberapa ketentuan yang antara lain ketentuan tersebut adalah ketentuan tentang biaya ta'widh dan denda.

Dalam iB Hasanah card yang ada di BNI Syariah sendiri ada beberapa biaya administrasi yang dikenakan kepada nasabah yaitu biaya keanggotaan, biaya ganti tadwidh atau keterlambatan. Menurut fatwa DSN-MUI tentang Syariah Card, dalam hal ini mengenai

1 Azharsyah Ibrahim, Kredit dalam Hukum Syariah (Kajian terhadap Akad dan Persyaratannya, Fakultas Syariah, IAIN Ar-Raniry Banda Aceh, 2010) hlm, 12. 
ta'widh biaya-biaya yang dikeluarkan terhadap penerbit kartu akibat keterlambatan pemegang kartu dalam membayar kewajibannya yang telah jatuh tempo. Biaya diterapkan kepada nasabah yang dengan sengaja atau karena kelalaian melakukan sesuatu yang menyimpang dari ketentuan akad dan menimbulkan kerugian pada pihak lain.

Kenyataan di masyarakat menunjukkan adanya perbedaan antara fatwa DSN-MUI dengan praktik di lapangan, utamanya terkait dengan biaya tadwidh itu sendiri. Selain itu, terdapat pula beberapa hal yang menjadi perdebatana, apakah syar'i atau tidak. Berdasarkan pada hal tersebut, maka penelitian ini dilakukan untuk menelaah unsur syar’i dari aplikasi iB Hasanah oleh Bank Nasional Indonesia.

\section{TINJAUAN TEORITIK}

\section{Konsep Maslahah}

Maslahah merupakan salah satu metode penetapan hukum syara' yang digunakan dalam proses ijtihad yang lebih banyak menekankan pada aspek mendahulukan kemaslahatan dan meniadakan kemadaratan dalam pengambilan keputusan hukum. Namun setiap mashlahah yang bertentangan dengan al-Qur'an, Sunnah, atau ijma' bisa menjadi batal dan harus dibuang jauh-jauh. ${ }^{2}$

Ahli hukum terkemuka, Mustafa Zaid menyatakan bahwa, para ulama nahwu dan sharaf (gramatika bahasa Arab), menetapkan bahwa kata mashlahah sepadan dengan kata mafalah yang berasal dari kata sulhu yang berarti hal yang baik. Dikatakan pula bahwa mashlahah itu mengandung pengertian "kelezatan" dan "hal yang dapat membawa pada kelezatan", sedang kata mafsadah artinya "kerusakan" dan "hal yang dapat membawa pada kerusakan”. Karena itu, Mustafa Zaid menyimpulkan bahwa, keduanya mencakup arti jasmani dan rohani, duniawi dan ukhrawi. ${ }^{3}$

Imam al-Ghazali memandang bahwa suatu kemaslahatan harus sejalan dengan tujuan syara', sekalipun bertentangan dengan tujuan-tujuan manusia, karena kemaslahatan manusia tidak selamanya didasarkan kepada kehendak syara', tetapi sering didasarkan kepada kehendak hawa nafsu.Oleh sebab itu, yang dijadikan patokan dalam mentukan kemaslahatan itu adalah kehendak dan tujuan syara', bukan kehendak dan tujuan manusia. Oleh karenanya, kemaslahatan yang dapat dijadikan pertimbangan (landasan) untuk menetapkan hukum menurut al-Ghazali adalah apabila: Pertama, mashlahah itu sejalan dengan jenis tindakan-tindakan syara'. Kedua, mashlahah itu tidak meninggalkan atau

2 Enden Haetami,"Perkembangan Teori Maslahah"Izzu al-Din Bin Abd al-Salam Dalam Sejarah Pemikiran Hukum Islam”, Asy-Syari’ah 17, No.1, (April 2015), h.29

3 Hasnan Bachtiar, "Maslahah Dalam Formasi Teori Hukum Islam", Ulumuddin 4, (JanuariJuni 2009), h.279 
bertentangan dengan nash syara'. Ketiga, mashlahah itu termasuk ke dalam kategori mashlahah yang dhoruri, baik yang menyangkut kemaslahatan pribadi maupun orang banyak dan universal, yaitu berlaku sama untuk semua orang. ${ }^{4}$

\section{Teori Perilaku}

Teori ekonomi perilaku konsumen, yang biasanya hanya disingkat teori konsumen yang menerangkan perilaku konsumen dalam membelanjakan pendapatanya untuk memperoleh alat-alat pemuas kebutuhan, yang dapat berupa barang-barang dan konsumsi ataupun jasa-jasa konsumsi. Fungsi utama barang dan konsumsi adalah umumnya adalah rumah tangga keluarga. Dalam kedudukannya sebagai barang-barang dan jasa-jasa konsumsi mereka disebut konsumen. 5

Perilaku konsumen (consumer behavior) merupakan "tindakan langsung dalam mendapatkan, mengkonsumsi serta menghabiskan produk dan jasa, termasuk proses keputusan yang mendahului dan mengikuti tindakan tersebut. ${ }^{6}$

Semua hal yang penting dalam perilaku konsumen adalah bahwa seorang konsumen selalu dianggap sebagai manusia yang rasional. Rasionality didefinisikan sebagai tindakan manusia dalam memenuhi keperluan hidupnya, yaitu memaksimalkan keputusan senantiasa berdasarkan pada keperluan (need) dan keingian (want) yang digerakkan oleh akal yang sehat dan tidak akan bertindak secara sengaja membuat keputusan yang bisa merugikan keputusan mereka. Asumsi dasar tentang perilaku seorang konsumen yaitu: memaksimumkan kepuasannya, kesejahteraan, kemakmurannya atau kegunaannya dan berusaha mencapainya. ${ }^{7}$

Dalam ilmu ekonomi konvensional, tujuan konsumen dari kegiatan konsumsinya adalah memaksimumkan kepuasan materiil. Hal ini berarti dalam teori konvensional diajarkan bahwa tujuan konsumsi adalah mencari utility maksimum, di mana tingkat kepuasan seorang konsumen dalam mengkonsumsi suatu komoditi akan mencapai titik maksimum apabila ia memilih barang yang paling disenanginya, memiliki barang lebih banyak dari pada memiliki sedikit barang (more is better) serta menghabiskan seluruh anggaran atau pendapatan yang dimiliki. teori tersebut mengisyaratkan kepada kita bahwa

4 Muhammad Harfin Zuhdi, "Formulasi Teori Maslahah Dalam Paradigma Pemikiran Hukum Islam Kontemporer", Istinbath 12, No.1. (Desember 2013), h.291 h. 143 . 5Soediyono Reksoprayitno, Pengantar Ekonomi Makro, (Yogyakarta:BPFE Yogyakarta, 2002),

${ }^{6}$ Sutisna, Perilaku Konsumen Dan Komunikasi Pemasaran, (Bandung: PT. Remaja Rosdakarya Offset, 2003), cet. Ke-3, h. 5 . h. 188.21

7Muhammad, Mikro Ekonomi dalam Perspektif Islam, (Yogyakarta: BPFE-Yogyakarta, 2005), 
tindakan konsumen dalam mengkonsumsi barang dan jasa agar konsumen mencapai tujuannya (maximum utility), di mana tingkat kepuasan seorang konsumen dalam mengkonsumsi suatu komoditi akan mencapai titik maksimum apabila ia memilih barang yang paling disenanginya, memiliki barang yang lebih banyak baik dari pada memiliki sedikit (more is better) serta dapat menghabiskan seluruh anggaran atau pendapatan yang dimiliki. Dengan kesimpulan ini jelaslah bahwa yang di maksud kepuasan dalam ilmu ekonomi konvensional adalah kepuasan yang bersifat materiil.

Dalam ekonomi Islam, konsumen cenderung untuk memilih barang dan jasa yang memberikan maslāhah maksimum. Konsumsi dalam Islam dibedakan atas konsumsi duniawi, yaitu konsumsi untuk pemenuhan jasmani dan rohani. Konsumsi akhirat, yaitu konsumsi untuk kepentingan ibadah termasuk ibadah yang berdimensi sosial seperti pengeluaran sedekah, infak, zakat dan wakaf.

Sesuai dengan rasional Islami bahwa setiap perilaku ekonomi selalu ingin meningkatkan maslāhah yang diperolehnya. Keyakinan bahwa ada kehidupan dan pembalasan yang adil di akhirat serta informasi yang berasal dari Allah SWT. Maslāhah adalah suatu yang dapat memberikan keputusan karena kandungan maslāhah adalah terdiri dari manfaat dan berkah. Perilaku konsumen Muslim dalam hal ini yaitu, seorang konsumen akan mempertahankan manfaat dan berkah yang dihasilkan dari kegiatan konsumsinya. Konsumen merasakan adanya manfaat suatu kegiatan konsumsi ketika ia mendapatkan pemenuhan kebutuhan fisik, psikis dan material. Di sisi lain, berkah akan diperoleh ketika ia mengkonsumsi barang atau jasa yang dihalalkan oleh syariat Islam. ${ }^{8}$

Ekonomi Islam bukan hanya berbicara tentang pemuasan materi yang bersifat fisik, tapi juga berbicara cukup luas tentang pemuasan materi yang bersifat abstrak, pemuasan yang lebih berkaitan dengan posisi manusia sebagai hamba Allah swt.

\section{Kebutuhan dalam Islam}

Kebutuhan Dharuriyyah

Daruriyyah adalah sesuatu yang wajib adanya menjadi pokok kebutuhan hidup untuk menegakkan kemaslahatan manusia. Kebutuhan dharuriyyah dalam pengertian ini berpangkal daripada pemeliharaan lima hal, yaitu: agama, jiwa, akal, kehormatan, dan harta.

\section{$\underline{\text { Kebutuhan Hajiyah }}$}

8Pusat Pengkajian dan Pengembangan Ekonomi Islam, Ekonomi Islam, (Jakarta: PT. Raja Grafindo Persada, 2008), h. 129. 
Kebutuhan ini maksudnya untuk memudahkan, menghilangkan kesulitan atau menjadikan pemeliharaan yang lebih baik terhadap lima unsur pokok kehidupan manusia. Pada dasarnya jenjang hajiyah ini merupakan pelengkap yang mengokohkan, menguatkan, dan melindungi jenjang dharuriyyah. Atau lebih spesifiknya lagi bertujuan untuk memudahkan atau menghilangkan kesulitan manusia di dunia. 9

\section{$\underline{\text { Kebutuhan Tahsiniyah }}$}

Tahsiniyah adalah sesuatu yang diperlukan oleh norma atau tatanan hidup serta perilaku menurut jalan yang lurus. Hal yang bersifat tahsiniyah berpangkal dari tradisi yang baik dan segala tujuan perikehidupan manusia menurut jalan yang baik. Secara lebih spesifik tahsiniyah adalah semua barang yang membuat hidup menjadi lebih mudah dan gampang tanpa berlebih-lebihan atau bermewahan, seperti makanan yang baik, pakaian yang nyaman, peralatan kecantikan, interior rumah yang tertata lengkap dan tertata indah, serta semua barang yang menjadikan hidup manusia menjadi lebih baik.

\section{METODE PENELITIAN}

\section{Jenis Penelitian}

Jenis penelitian yang digunakan dalam penelitian ini merupakan jenis penelitian kualitatif deskriptif. Walaupun berjenis penelitian deskripsi namun studi ini tidak hanya mendeskripsikan data kualitatif yang diperoleh, lebih dari itu data diinterpretasikan agar menjadi wacana dan konklusi dalam berpikir logis, praktis, dan teoritis. ${ }^{10}$ Dimana penelitian kualitatif berdasar pada fenomena atau realita sosial yang terjadi.

Penelitian ini dilakukan dengan melihat dan mengeksplor tanggapan mengenai praktik kartu kredit syariah dalam hal ini aplikasi iB Hasanah Card dari berbagai sudut pandang sehingga dikatakan penelitian ini adalah penelitian multidimensi perspektif, penelitian ini dilakukan untuk melihat sejauh mana kiprah kartu kredit syariah di dukung karena fatwa DSN-MUI dan pihak perbankan yang membolehkan dan mengeluarkan konsep syariah card akan tetapi menjadi hal yang simpang siur kesyariahannya.

\section{Pendekatan Penelitian}

Jenis penelitian yang digunakan dalam penelitian ini adalah penelitian kualitatif yang berdasarkan pada pendekatan interpretatif. Pendekatan interpretatif dalam hal ini adalah melakukan eksplorasi terhadap fenomena-fenomena praktik syariah card ini dengan

9Ika Yunia Fauzia, dkk, Prinsip Dasar Ekonomi Islam, (Sidoarjo: Kencana, 2014), hal. 68.

${ }^{10}$ Surakhmad, Winarno. Pengantar Interaksi Belajar Mengajar, Dasar dan Tekhnik Metodologi Pengajaran. (Bandung: Tarsito. 1982) Hal 139 
menganalisa alasan-alasan yang melatar belakangi fenomena tersebut. Dengan imbuhan melakukan eksplorasi terhadap kesesuaian prinsip syariah card dari berbagai sudut pandang perspektif hingga hasil penelitian-penelitian akan memuat pandangan-pandangan tentang syariah card secara multidimensi.

\section{Pengumpulan Data}

Data yang dibutuhkan dalam penulisan ini secara umum terdiri dari data yang bersumber dari penelitian lapangan. Adapun metode pengumpulan data yang digunakan dalam penelitian ini adalah studi pustaka, wawancara, dan dokumentasi.

Teknik pengumpulan data studi pustaka dilakukan melalui penelusuran dengan menggunakan referensi dari buku, jurnal, makalah dan perundang-undangan terkait iB Hasanah Card maupun teknik analisis yang digunakan.

Pada teknik pengumpulan data melalui wawancara, peneliti terlibat langsung dengan narasumber sebagai pemberi informasi serta konfirmasi dalam penelitian ini. Dimana data yang diperoleh akan dijadikan dasar dalam menginterpretasikan, menemukan dan menjawab permasalahan penelitian. Untuk wawancara mendalam dilakukan secara langsung dengan informan secara terpisah di lingkungannya masing-masing.

Dalam melaksanakan metode dokumentasi, peneliti menyelidiki benda-benda tertulis seperti buku-buku, majalah, dokumen, catatan harian, dan sebagainya. Hasil penelitian dari observasi dan wawancara, akan lebih kridibel/dapat dipercaya bila didukung dengan dokumentasi.

\section{Pengolahan Data}

Analisis data dalam sebuah penelitian sangat dibutuhkan bahkan merupakan bagian yang sangat menentukan dari beberapa langka penelitian sebelumnya. Dalam penelitian kualitatif, analisis data harus seiring dengan pengumpulan fakta-fakta dilapangan, dengan demikian analisis data dapat dilakukan sepanjang proses penelitian dengan menggunakan tekhnik analisa.

\section{HASIL DAN PEMBAHASAN}

\section{Operasional iB Hasanah Card Bank BNI Syariah}

iB Hasanah Card adalah kartu pembiayaan yang berfungsi seperti kartu kredit sesuai dengan prinsip syariah dengan menggunakan akad kafalah, qardh, dan ijarah yang insya Allah membawa berkah. iB Hasanah Card tidak dapat digunakan ditempat maksiat. iB 
Hasanah Card adalah kartu yang berfungsi seperti kartu kredit sehingga diterima diseluruh tempat usaha bertanda Master Card dan semua ATM yang bertanda CIRRUS di seluruh dunia.

Operasional awal, pihak bank BNI Syariah mengerahkan tim marketing atau kampasing dalam menawarkan produk iB Hasanah Card pada tiap kantor, perusahaan, maupun individu. Kemudian arus bisnis dari Hasanah Card diawali dengan pengajuan aplikasi oleh nasabah pemohon kepada pihak issuer bank yang dalam hal ini adalah BNI Syariah. Dilanjutkan dengan proses scoring/verifikasi berdasarkan aplikasi yang dilakukan oleh nasabah. Jika proses scoring/verifikasi telah selesai dilaksanakan maka proses approval adalah langkah berikutnya.

Akad yang diterapkan pada Hasanah Card adalah akad kafalah, ijarah dan qard. Kesemuanya dipergunakan sesuai transaksi yang berlangsung. Akad tersebut menjadi dasar Hasanah Card menetapkan tarif charge atau biaya yang dikenakan kepada pemegang kartu hal ini yang membedakan antara kartu kredit konvensional. Dalam Hasanah Card semua jelas peruntukannya untuk penetapan biaya.

Misal akad Qardh digunakan pada saat tarik tunai di ATM, Qardh merupakan akad utang piutang, dalam akad ini berapapun jumlah uang yang dipinjamkan itu yang akan dikembalikan dari pihak nasabah tanpa ada penambahan bunga ataupun pengurangan dari pokoknya. Pengenaan biaya pada transaksi tarik tunai hanya dikenakan biaya administrasi fungsi dari atm, biaya sudah ditentukan di awal pada saat penandatanganan aplikasi dan ini bukan termasuk riba. Biaya yang dikenakan pada setiap transaksinya sebesar Rp. 25.0oo akan tetapi biaya ini bukan diperuntukkan kepada pihak bank BNI Syariah melainkan diterima oleh pihak ATM atau CIRRUS yaitu vendor dari ATM.

Hasil penelitian menunjukkan bahwa penerapan akad Qardh pada iB Hasanah Card sejalan dengan teori Maslahah yang dikemukakan oleh Imam al-Ghazali yang memandang bahwa suatu kemaslahatan harus sesuai dengan tujuan syara, sekalipun bertentangan dengan tujuan-tujuan manusia, dimana pada penerapannya Bank BNI Syariah murni untuk membantu nasabah yang membutuhkan uang dari penarikan tunai meskipun tidak mengambil keuntungan atau imbalan dari proses tersebut, karena pada dasarnya kemaslahatan menekankan untuk mendahulukan sesuatu yang asalnya baik dan meniadakan kemudharatan. Namun realita pada Bank Konvensional kemaslahatan manusia tidak selamanya didasarkan kepada kehendak syara', tetapi sering didasarkan kepada kehendak hawa nafsu. Jika pada Bank Konvensional terdapat Bunga yang artinya hal tersebut bertentangan dengan syara' yang akan menimbulkan kerugian disalah satu pihak, itu tidak 
dibenarkan. Karena sebab yang dijadikan patokan dalam mentukan kemaslahatan itu adalah kehendak dan tujuan syara', bukan kehendak dan tujuan manusia. ${ }^{11}$

Pada dasarnya bunga yang diterapkan dalam Bank Konvensional termasuk kategori Riba dayn yang berarti tambahan, yaitu pembayaran premi atas setiap jenis pinjaman dalam transaksi utang-piutang maupun perdagangan yang harus dibayarkan oleh peminjam kepada pemberi pinjaman disamping pengembalian pokok yang ditetapkan sebelumnya. Inti dari riba pinjaman (riba dayn) adalah tambahan pokok yang ditetapkan sedikit maupun banyak.

Begitupun dengan akad ijarah bank menetapkan biaya sewa sebesar biaya yang dikeluarkan atas kerjasamanya dengan merchant. Dengan akad kafalah bank menetapkan iuran biaya untuk mengcover resiko yang timbul. Dari ke dua akad inilah pihak bank mendapatkan keuntungan yang disebut ujrah atau biaya sewa.

\section{Mekanisme Biaya Tadwidh Biaya Keterlambatan dan Penetapan Biaya iB Hasanah Card}

Pada prakteknya, Penerapan biaya keterlambatan pada BNI Syariah dalam aplikasi iB Hasanah Card, dikenakan pada saat adanya tunggakan dari nasabah atau pengguna kartu lewat jatuh tempo. Biaya denda keterlambatan tersebut dihitung secara harian atau dengan kata lain biaya tadwidh ditentukan berdasarkan waktu, dimulai dai o-6 hari, kemudian 14 hari dst, selama si nasabah belum melunasi pembayaran yang ditagihkan biaya denda akan terus meningkat. Menurut dewan direksi BNI Syariah Kota Makassar memberlakukan biaya denda merupakan hukuman efek jera pada si nasabah, agar tidak lalai dalam melakukan pembayaran dan tidak melakukan tunggakan, karena bagaimanapun resikonya, tetap nasabah yang akan rugi karena semakin banyak jumlah yang harus dibayarkan.

Berdasarkan hal ini penagihan biaya tadwidh atau denda keterlambatan yang berdasarkan waktu bukan berdasarkan kebutuhan bank dapat dikatakan telah sesuai dengan prinsip syariah. Karena pihak dewan direksi telah mengeluarkan kebijakan meskipun DPS membolehkan hal tersebut.

Adapun langkah yang dihadapi pihak BNI Syariah, pada saat nasabah atau pengguna kartu yang terlambat dan menunggak dalam pembayaran, akan dikenakan SP 1 ini dikenakan pada waktu 1 minggu nasabah terlambat membayar, kemudian bulan ke 2 akan diberikan teguran melalui surat peringatan ke 2 dan panggilan telepon.

Kemudian jika bulan ketiga sama sekali tidak ada respon dari nasabah, dinyatakan kredit macet atau over limit, pihak BNI Syariah akan menon-aktifkan aplikasi dan

${ }^{11}$ Muhammad Harfin Zuhdi, "Formulasi Teori Maslahah Dalam Paradigma Pemikiran Hukum Islam Kontemporer”, Istinbath 12, No.1. (Desember 2013), hal.291 
penghapusan buku. Pihak BNI Syariah tidak menyediakan Debt Collector, langkah terakhir yang ditempuh adalah dengan jalur hukum yaitu pelelangan akan tetapi sistem yang digunakan adalah sistem keadilan, yang mana pihak bank hanya mengambil sisa pokok pembiayaan, margin/keuntungan tidak akan dihitung lagi, jika ada sisa dikembalikan kepada pihak nasabah.

Landasan utama dan Dasar BNI Syariah Kota Makassar masih tetap bertahan menerapkan eksistensinya pada produk syariah Card, menilik bahwa Bank syariah lain menolak dan memberhentikan aplikasinya, dengan alasan, Pihak BNI Syariah berusaha mengkaji agar sistem yang diterapkan sesuai dengan syariah.

\section{KESIMPULAN}

Masjid belum digunakan untuk tempat kegiatan ekonomi, karena beberapa faktor, yaitu: Persepsi (pemahaman) yang keliru, bahwa masjid tidak boleh digunakan selain sebagai tempat ibadah, pengurus masjid tidak ada yang mau mengelolanya, pengurus masjid tidak ada yang mampu mengelolanya, tidak ada modal, sulit mencari orang yang dapat dipercaya untuk mengelolanya, kuatir fungsi masjid sebagai tempat ibadah tidak menjadi perhatian utama, lokasinya tidak/ kurang cocok (tidak strategis), tidak mendapat dukungan dari jama'ah dan pengurus lain, belum maksimal sosialisasi kepada jamaah dan pengurus lain.

Jika ditelaah lebih jauh, maka dipahami bahwa faktor-faktor penyebab belum difungsikannya masjid di Kota Watampone sebagai tempat usaha ekonomi itu dapat dikelompokkan berdasarkan unsur penyebabnya ke dalam empat faktor, yaitu; Faktor persepsi (pemahaman) yang keliru, faktor keterbatasan SDM, faktor keterbatasan modal, faktor letak yang kurang strategis

Upaya yang Dapat Dilakukan untuk Memberdayakan Ekonomi Masyarakat Melalui Masjid. Pemberdayaan ekonomi masyarakat melalui masjid dapat dilakukan dengan berbagai cara yang terkoordinasi, terncana, dan tertata dengan baik antara pengurus masjid dengan masyarakat yang membutuhkan lapangan kerja. Selama mampu dikelola dengan baik, bertanggungjawab, dan penghasilannya lumayan, maka usaha apapun boleh dilakukan untuk pemberdayaan ekonomi berbasis masjid. Cara-cara yang dapat ditempuh berdasarkan hasil penelitian adalah: Menjadikan masjid sebagai pusat kegiatan ekonomi, disamping sebagai tempat ibadah, mengangkat pengurus masjid yang memiliki kemampuan untuk mengelola masjid sebagai pusat bisnis dan dapat dipercaya, membentuk Koperasi, BMT, atau Lembaga Ekonomi di masjid yang ditangani oleh orang yang mampu dan dapat dipercaya, memberikan peluang kepada masyarakat untuk menggunakan tempat, pekarangan, atau sarana masjid 
yang selama ini tidak difungsikan guna membuka usaha atau berdagang, membuka lapaklapak di pekarangan dan sekitar masjid.

Sekalipun peran dan fungsi masjid sebagai pusat kegiatan ekonomi umat saat ini di Kota Watampone masih sangat minim, tetapi tidak berarti tidak memiliki prospek yang cerah di masa yang akan datang. Terbukti beberapa masjid di Kota Watampone telah memulai beberapa usaha ekonomi untuk menambah pendapatan kas masjid.

Prospek pengembangan usaha-usaha ekonomi yang telah ada tersebut maupun potensi pengembangan usaha yang belum diadakan memiliki peluang untuk berkembang dan maju. Hal ini dikarenakan adanya dukungan dari masyarakat yang cukup besar yang didorong oleh aspek psikologis keagamaan (keyakinan) umat Islam. Ajaran agama Islam yang dijunjung tinggi oleh penganutnya merupakan modal besar yang membentuk dorongan emosional untuk memajukan kepentingan masjid dan umat Islam melalui pemberdayaan ekonomi.

Prospek pemberdayaan ekonomi berbasis masjid di Kota Watampone cukup besar. Namun demikian, untuk mewujudkan hal itu, membutuhkan upaya berkesinambungan, terprogram dengan baik, dan melibatkan dukungan banyak pihak. Sehingga perwujudannya masih membutuhkan waktu yang relatif cukup lama.

\section{KESIMPULAN}

Berdasarkan pada hasil pembahasan dan penelitian, maka dapat ditarik beberapa kesimpulan sebagai berikut. Pertama, Bank BNI Syariah Kota Makassar pada umunya sudah menjalankan operasional Ib Hasanah Card sesuai dengan fatwa yang berlaku No:54/DSNMUI/X/2006 tentang Syariah Card. Sebagai Bank Syariah, BNI Syariah berusaha untuk selalu menerapkan prinsip-prinsip syariah dalam menjalankan Hasanah Card. Hal tersebut dapat dilihat dari usaha BNI Syariah dalam menyempurnakan dan terus mengkaji produk kartu kredit syariahnya, Dalam usaha menghindari praktek riba, gharar dan israf. Namun pada realitanya pihak bank belum sepenuhnya mampu mengkordirnir pengeluaran anggota nasabah sehingga masih banyak yang mengalami over limit atau kredit macet, meskipun telah ditetapkan pagu maksimal, karena menurut pihak bank BNI Syariah Makassar kebaradaan kartu kredit syariah untuk memenuhi kebutuhan konsumtif masyarakat.

Kedua, untuk menghindari praktek riba, BNI Syariah tidak mengambil keuntungan dalam transaksi utang piutang, dan akan menonaktifkan Hasanah Card bagi nasabah yang lalai membayar kewajiban bulanannya sampai kewajiban itu terlunasi, serta menghapuskan biaya denda yang sama diberlakukan oleh pihak bank konvensional, agar tidak terjadi utang yang berlipat ganda. Sedangkan untuk menghindari peraktek israf BNI Syariah melakukan beberapa hal yaitu menetapkan pagu maksimal pembelanjaan agar nasabah tidak menjadi 
konsumtif. Namun pada realitanya pihak bank belum sepenuhnya mampu mengkordirnir pengeluaran anggota nasabah sehingga masih banyak yang mengalami over limit atau kredit macet, meskipun telah ditetapkan pagu maksimal, karena menurut pihak bank BNI Syariah Makassar kebaradaan kartu kredit syariah untuk memenuhi kebutuhan konsumtif masyarakat.

\section{DAFTAR PUSTAKA}

Al-Haritsi, Ahmad. 2010. Al-Fiqh AI-Iqtishadi li Amiril Mukminin Umar Ibn Al-Khaththab, diterjemahkan oleh Asmuni Solihan Zamalchsyari. Jakarta

Arikunto, Suharsimi. 2002. Prosedur Penelitian Suatu Pendekatan. Rineka Cipta: Jakarta

Atkinson, Rita. Atkison, Richard. 1982. Pengantar Psikologi. Erlangga: Jakarta

Baalbaki, Munir. 2006. Kamus AlMaurid. Halim Jaya: Surabaya

Bachtiar, Hasnan. 2009. Maslahah Dalam Formasi Teori Hukum Islam. Ulumuddin 4

Basyir, Azhar, Ashari. 2000. Asas-asas Muamalat (Hukum Perdata Islam). UII Press: Yogyakarta

Burhan, Bungin. 2003. Analisis Data Penelitian Kualitatif, Pemahaman Filosofis dan Metodologis ke Arah Penguasaan Model Aplikasi. PT. Raja Grafindo Persada: Jakarta

Denzim. Lincoln. 1994. Hand Book of Qualitative Research, Sage Publication. Thousan oaks: London.

Departemen Agama RI Al-Quran dan Terjemahnya. 2009. AL-QuranulKarim. PT Sygma Examedia Arkanleema: Bandung

Fauzia, Yunia, Ika.Dkk. 2014. Prinsip Dasar Ekonomi Islam. Kencana: Sidoarjo

Ghozali dan Chariri, 2017. Teori Akuntansi. BadanPenerbit UNDIP: Semarang

Haetami, Enden. 2015. Perkembangan Teori Maslahah "Izzu al-Din Bin Abd al-Salam Dalam Sejarah Pemikiran Hukum Islam. Asy-Syari'ah

Hidayat, Ganjar. 2012. Tinjauan Hukum Islam Terhadap Kartu Kredit Syariah (Studi Tentang IB Hasanah Card BNI Syariah). Skripsi. UIN Sunan Kalijaga: Jogyakarta

Ibrahim, Johanes. 2004. Kartu Kredit Dilematis Antara Kontrak dan Kejahatan. Refika Aditama: Bandung

Ibrahim, Azharsyah. 2010. Kredit dalam Hukum Syariah (Kajian terhadap Akad dan Persyaratannya). Skripsi. Fakultas Syariah, IAIN Ar-Raniry: Banda Aceh

Indriantoro, Nur. Supomo, Bambang. 2013. Metodologi Penelitian Bisnis Untuk Akuntansi dan Manajemen. BPFE: Yogyakarta 
Johannes, Ibrahim. 2004. Kartu Kredit Dilematis Antara Kontrak dan Kejahatan. PT Refika Aditama: Bandung

Kahf, Mozer. Dkk. 2010.Tanya Jawab Keuangan dan Bisnis Kontemporer Dalam Tinjauan Syariah. PT. Aqwam Media Profetika: Solo

Karim, Adiwarman. 2004. Bank Islam Analisis Fiqh dan Keuangan. PT. Raja Grafindo Persada: Jakarta

Moleong. 2011. Metodologi Penelitian Kualitatif Edisi Revisi. PT Mizan Publika: Bandung

Muhammad, 2005. Mikro Ekonomi dalam Perspektif Islam. BPFE: Yogyakarta

Muis, Hidayat. 2012. Analisis Penerapan Fatwa DSN-MUI/vii/2004 Tentang Ta'widh pada Pembiayaan mudharabah di PT Syariah Bukopin, Skripsi. UIN Syarif Hidayatullah: Jakarta

Mustofa, Azmi, Ulul. 2015. Syariah Card Perspektif Al Maqashid Syariah.Jurnal. Vol. o1.

Notoatmojo, Soekidjo. 2007. Promosi Kesehatan dan Ilmu Perilaku, Rineka Cipta: Jakarta

Nasution, Edwain, Mustafa. Pengenalan Eksklusif Ekonomi Islam. Jurnal.

Pusat Pengkajian dan Pengembangan Ekonomi Islam. 2008. Ekonomi Islam. PT. Raja GrafindoPersada: Jakarta

Qadarwi, Yusuf.1997. Norma dan Etika Ekonomi Islam. Gema Insani Press: Jakarta

Reksoprayitno, Soediyono. 2002. Pengantar Ekonomi Makro. BPFE: Yogyakarta

Santosa, Edi. 2008. Syariah Card dan Aplikasinya Pada Produk Dirham Card di Bank Danamon Syariah. Skripsi. Universitas Islam Negeri Syarif Hidayatullah: Jakarta

Sarwono, Sarlito. 2002. Berkenalan dengan Aliran-Aliran dan Tokoh-Tokoh Psikologi. Bulan Bintang: Jakarta

Siamat, Dahlan. 2001. Manajemen Lembaga Keuangan. Skripsi. Fakultas Ekonomi, Universitas Indonesia: Jakarta

Silvia, Desti. 2004. Tinjauan Fiqh Muamalah Terhadap Pelaksanaan Penentuan Biaya (Fee) Pada Produk iB Hasanah Card di BNI Syariah Cabang Buah Batu Bandung. Skripsi. UIN Sunan Gunung Djati Bandung: Bandung

Sjahdeini, Rey, Sutan. 2014. Perbankan Syariah Produk-Produk dan Aspek Hukumnya, Prenadamedia Group: Jakarta

Sugiyono. 2013. Metode Penelitian Kuantitatif Kualitatif dan R\&D. Alfabeta: Bandung

Sukirno, Sadono. 2013. Mikroekonomi Teori Pengantar. PT Raja Grafindo Persada: Jakarta

Susilo, Sri, Y. 2000. Bank dan Lembaga Keuangan Lain. Salemba Empat: Jakarta

Sutisna. 2003. Perilaku Konsumen Dan Komunikasi Pemasaran. PT. Remaja Rosdakarya Offset: Bandung 
Ushwa, Nurul. 2016. Kajian Hukum Islam Terhadap Akad Kartu Kredit Hasanah Card Pada Bank Bni Syariah. Skripsi. Universitas Muhammadiyah Surakarta: Surakarta

Usman, Husain. Akbar, Purnomo. 2001. Metodologi Penelitian Social, Jurnal cet. IV: PT. Bumi Aksara: Jakarta

Walgito, Bimo. 1994. Psikologi Sosial. Andi Offset: Yogyakarta

Winarno, Surakhmad. 1982. Pengantar Interaksi Belajar Mengajar, Dasar dan Tekhnik Metodologi Pengajaran. Tarsito: Bandung:

W.Lawrence, Neuman. 2013. Metodologi Penelitian Sosial: Pendekatan Kualitatif dan Kuantitatif. Eds.7. Penerjemah: Edina T. Sofia. PT. Indeks: Jakarta

Zuhdi, Harfin, Muhammad. 2013. Formulasi Teori Maslahah Dalam Paradigma Pemikiran Hukum Islam Kontemporer. Jurnal. Istinbath 12 